https://doi.org/10.37816/2073-9567-2021-60-21-29

УДК 008

ББК 71(2)

This is an open access article distributed under

the Creative Commons Attribution 4.0

International (CC BY 4.0)

\author{
(C) 2021. Svetlana A. Simonova \\ Moscow, Russia \\ (C) 2021. Marianna A. Dudareva \\ Moscow, Russia
}

\title{
METAPHYSICS OF LABOR IN RUSSIAN CULTURE: PART TWO
}

Acknowledgements: This paper is performed with support of the Program of strategic academic leadership of Peoples' Friendship University of Russia (RUDN University).

Abstract: This paper is a continuation of a large study in two parts on the metaphysics of labor in Russian culture, literature and philosophy. In the second part of the work, the team of authors, continuing to consider the phenomenon of labor in synchronism and diachrony, addresses a person and its attitude towards work in a postmodern society. The phenomenon of labor is analyzed in close connection with economic, moral, axiological spheres of life of the modern man. One of the main issues in a current situation of globalism is the issue of relationship between categories of "labor" and "leisure". Can civilization be built on a foundation of leisure and not labor? Global transformation of the axiological status of labor has occurred in the culture of modern society. This process has got not only economic metrics associated with production and consumption, but also affects an axiological layer of culture associated with existential experiences of the individual. Man does not just work to satisfy his physical needs; the teleology of labor is always important, which implies answers to the questions: "For what does a person work?" and "For what is he ready to spend his free time of his life?" In a postindustrial, networked, consumer society, principles of the global Protestant work ethic, which constituted the foundation of capitalist civilization, no longer work. The study involved analytical, historical, descriptive and systematic methods of analysis.

Keywords: the value of labor, labor discourse, metaphysics, Russian culture, economic rationalism, working culture, motivation.

\section{Information about the authors:}

Svetlana A. Simonova - PhD in Philosophy, teacher, Moscow State University of Psychology \& Education (MSUPE), Sretenka St., 29, 127051 Moscow, Russia. ORCID ID: https://orcid.org/0000-0003-4506-1248. E-mail: jour2@yandex.ru

Marianna A. Dudareva - PhD in Philology, Senior lecturer of the Department of Russian language No. 2 FRYA and OD, Peoples' Friendship University of Russia (RUDN University), Miklukho-Maklay St., 6, 117198 Moscow, Russia. ORCID ID: https://orcid.org/0000-0002-4950-2322.E-mail: marianna.galieva@yandex.ru

Received: February 14, 2020

Date of publication: June 28, 2021 
For citation: Simonova S. A., Dudareva M. A. Metaphysics of labor in Russian culture: part two. Vestnik slavianskikh kul'tur, 2021, vol. 60, pp. 21-29. (In Russian) https://doi. org/10.37816/2073-9567-2021-60-21-29

$$
* * *
$$

(C) 2021 г. С. А. Симонова

г. Москва, Россия

(C) 2021 г. М. А. Дударева

г. Москва, Россия

\title{
МЕТАФИЗИКА ТРУДА В РУССКОЙ КУЛЬТУРЕ: ЧАСТЬ ВТОРАЯ
}

\author{
Публикация выполнена при поддержке Программы \\ стратегического академического лидерства РУДН
}

Аннотация: Данная статья представляет собой продолжение большого исследования в двух частях, посвященного метафизике труда в русской культуре, литературе и философии. Во второй части работы коллектив авторов, продолжая рассматривать феномен труда в синхронии и диахронии, обращается к человеку и его отношению к трудовой деятельности в условиях постмодернистского общества. В культуре современного общества произошла глобальная трансформация статуса труда. Этот процесс имеет не только экономические метрики, связанные с производством и потреблением, но затрагивает аксиологический пласт культуры, связанный с экзистенциальными переживаниями личности. Человек не просто трудится ради удовлетворения своих физических потребностей; всегда важна телеология труда, предполагающая ответы на вопросы: «во имя чего трудится человек?» и «на что он готов тратить свое свободное время своей жизни?». В этом контексте важнейшим вопросом является отношение к труду, поскольку сейчас имеет место девальвация трудовой этики. В постиндустриальном, сетевом, потребительском обществе больше не работают принципы глобальной протестантской этики труда, сформировавшей фундамент капиталистической цивилизации. Феномен труда анализируется в тесной связи с экономическими, моральными, аксиологическими сферами жизни современного человека. В работе задействованы аналитический, исторический, дескриптивный и системный методы анализа.

Ключевые слова: ценность труда, дискурс труда, метафизика, русская культура, экономический рационализм, трудовая культура, мотивация.

\section{Информация об авторах:}

Светлана Анатольевна Симонова - доктор философских наук, Московский государственный психолого-педагогический университет, Сретенка ул., д. 29, 127051 г. Москва, Россия. ORCID ID: https://orcid.org/0000-0003-4506-1248. E-mail: jour2@yandex.ru

Марианна Андреевна Дударева — кандидат филологических наук, старший преподаватель кафедры русского языка № 2 ФРЯ и ОД, Российский университет дружбы народов, ул. Миклухо-Маклая, д. 6, 117198 г. Москва, Россия. ORCID ID: https://orcid.org/0000-0002-4950-2322.E-mail: marianna.galieva@yandex.ru

Дата поступления статьи: 14.02.2020 
Дата публикации: 28.06.2021

Для цитирования: Симонова С. А., Дударева М. А. Метафизика труда в русской культуре: часть вторая // Вестник славянских культур. 2021. Т. 60. С. 21-29. https:// doi.org/10.37816/2073-9567-2021-60-21-29

\section{Introduction}

In 2019, a team of scientists, philosophers and cultural specialists planned to write a large-scale study on the philosophy of labor in Russia, the metaphysical foundations of the phenomenon of labor in the national space. In the context of globalism and the transitional nature of the $21^{\text {st }}$-century culture, not only political and economic issues come to the fore, but also problems associated with the spiritual life of the people, its subsurface depth, according to the philosopher I. A. Ilyin [4, c. 135]. This is what determines the relevance of the study, since today in the market conditions the nature of labor activity has changed significantly, a new philosophy of labor, moral labor standards are being developed, the axiological and ontological status of labor is changing. The first part of the work "Metaphysics of Labor in Russian Culture: Part One" was published in the journal "Amazonia Investiga" from the WoS International Database in Issue 23.

In the first part of the article devoted to the study of the metaphysical essence of labor in the Russian national image of the world, we turned to the works of Russian philosophers of the $19^{\text {th }}$ and early $20^{\text {th }}$ centuries, N. F. Fedorov, V. S. Soloviev, S. N. Bulgakov, N. A. Berdyaev. Much attention was paid to the ambivalent nature of the labor phenomenon in Russian culture [14]. The concept of "labor" was considered and from a linguistic point of view, the topic of labor in paremias was analyzed. We are interested in the phenomenon of labor in synchrony and diachrony - how the philosophy of work originated in Russia, how philosophers, writers (we turned to the heritage of Leo Tolstoy) and ordinary people in everyday life relate to work. In the second part of the study, we turn to the phenomenon of labor in modern Russia, in a postmodern society, and in the world, examining labor in connection with morality, culture, economy, etc. Appeal to modern society and analysis of human labor activity today allows us to trace the transformation of the philosophy of work in Russian culture.

\section{Materials and methods}

The methodology of the study of the metaphysical foundations of labor in Russian culture is reduced to the consideration of the phenomenon of labor in synchrony and diachrony using analytical, historical, descriptive and systematic methods of analysis. These methods make it possible to comprehensively approach the problem and see how the philosophy of work was formed in Russia and what its foundations are (religious, philosophical, economic, etc.).

So, in Russian philosophy and other intellectual heritage, you can find the idea of the possibility of freedom in the conditions of a determined nature and God need to earn a living by physical labor, postulating overcoming the material spiritual with the help of creative labor. Taking the work beyond the framework of the "work-earnings" scheme and substantiating the idea, first of all, of the moral and spiritual necessity of work, the Russian philosophers thus created a space of moral freedom in relation to the labor aspect of life.

This doesn't correspond to the widespread ungodly myths about the laziness of the Russian people, about the apology of idleness, etc. Quite the contrary, the presence of a developed philosophy of labor (specifically, the philosophy of economy) shows and proves that labor in all aspects (spiritual, moral) always had a high status, since this was reflected 
in philosophical reflection, which is distinguished by the creation of a national philosophical school dedicated to comprehension of the essence of labor.

Thus, in Russian philosophy, clear moral foundations of honest labor are established, and moral standards of labor in the Russian mentality serve as a substitute for labor lawyer's work and rationalism in the West. In this sense, we can say that in Russia there is a specific ethics of labor, based on the principles of the philosophy of economy.

Among the many transformations that modern society is undergoing, one of the most significant is the modification of the nature of labor. This process has not only economic metrics associated with production and consumption, but also affects the axiological layer of culture associated with the existential experiences of the individual. Man does not just work to satisfy his physical needs; the teleology of labor is always important, which implies answers to the questions: "For what does a person work?" and "In what is he ready to spend his free time in his life?"

In this context, the most important issue is the attitude to work, since now there is a devaluation of labor ethics. In a 2004 dissertation, the author writes: "Today, an "economically rational" person dominates in society, for whom labor is not in itself human activity full of meaning, but a means of obtaining monetary compensation" [2, c. 3].

These are very accurate words describing the motivation of the labor activity of a modern person. Today, we can say that economic rationalism prevailed in the system of axiological priorities of culture. Labor is perceived solely as an economic category, and not a spiritual and moral value, as it was, for example, in the traditions of Russian philosophy and Christian ethics. However, these traditional values today have ceased to have that power of influence on the spiritual culture of society, which could have a transformative value for the individual. This is largely due to the transformation of moral values that have changed in the applied and pragmatic field.

The current situation in the field of morality is quite accurately described by the wellknown ethical philosopher A. V. Razin: "Traditions in which the foundation of initial moral principles was seen in many respects have often been destroyed. They lost their significance in connection with global processes developing in society, and the rapid pace of change in production, its reorientation to mass production. As a result of this, a situation arose in which opposing moral principles appeared equally justified, equally derived from the mind" [11, c. 16].

This is evidence of the relativization of moral values, which leads to significant transformations in the axiosphere in general. The subject field of ethics has changed: ethics becomes an interdisciplinary science, closely interacting with such pragmatic sciences as psychology, management, intercultural communications, conflict studies, etc. Instead of the metaphysical problems that have traditionally worried ethical thought, ethics drift towards technology, which, in essence, corresponds to the pragmatic mood of the whole culture.

Naturally, the attitude to work, and the very nature of labor in this situation have changed. Nowadays, few people speak about ethics, much less about the metaphysics of labor. Labor is inscribed in the system of modern technologies and its essence is no longer directed towards the spirituality of man. But we believe that this is fraught with significant moral losses; if labor is no longer just alienated, as it was before in the industrial era, but by the very alienation of man from his spiritual essence, then this is evidence of a deep crisis of European spiritual culture, to which Russia belongs organically.

Astute Western philosophers have spoken about this crisis for a long time, starting from the $19^{\text {th }}$ century. The most striking figures, from our point of view, are F. Nietzsche, 
J. Heising, A. Schweitzer, M. Heidegger, P. Sloterdijk, J. Lipovecki and others. The last one, by the way, is the author of a very successful metaphor of the "era of emptiness", which describes the spiritual state of a modern consumer society. In his book, he wrote: "the more people try to express themselves, the less meaning we find in their expressions; the more they strive for subjectivity, the more obvious is anonymity and emptiness" [6, c. 31].

This book was written in the early 80 s of the $20^{\text {th }}$ century, and today the situation has gone far ahead in a negative sense. And now, what a well-known modern researcher V. G. Shukin already says: "In the last two decades, due to the natural change of generations, the collective-farm and state-farm cultural type has been replaced by the "pop" man, i.e. mass consumer culture, vivid examples of which are McDonald's restaurants or base militants" [13, c. 70].

In such a situation, labor does not just have an alienated form, it loses all moral meaning at all, loses its, perhaps its main property, humanity, as the modern author says as follows: "Labor as an activity is only expedient human activity, in which the assignment of someone else's finite is excluded. product - this is, firstly, and secondly, labor, as a social quality inherent only to a person (society), is a process of a person's inner experience that elevates his person human qualities are humanity" [9, c. 153]. Here we are talking about the deepest anthropological property of man, which consists in the fact that labor is able to elevate a person to his humanity.

\section{Results}

Of course, one cannot go to extremes and belittle the pragmatic aspect of labor, but it is necessary not to lose sight of the spiritual and moral aspects of work. In general, a decrease in the axiological status of labor is characteristic not only for Russia, but also for the entire modern consumer society, which changes both the motivation of labor activity and the axiological status of labor. Overgrown consumption is a negative factor in modifying the nature of labor in the modern world. Consumer society is directed towards a hedonistic way of life in which labor has no moral value.

However, there is an objective background of a civilizational nature, which also has a significant impact on the status of work. This is the emergence of a new anthropological type of symbolic analysts, which replaces the homo faber. Relatively speaking, manual labor has lost its primacy, giving way to intellectual work associated with the high technology of modern civilization. "Among the symbolic analysts are scientists and researchers, management, marketing and advertising consultants, specialists who work with oral and visual symbols (musicians, representatives of the film industry, etc.)" [12, c. 21].

In addition, an essential aspect of the problem lies in the fact that modern working culture is being modified in such a way that leisure penetrates labor. An essential aspect of the problem is that modern working culture is being modified in such a way that leisure penetrates labor. M. Mayatsky draws attention to this: "Theoretically," the researcher notes, "it is possible to rebuild all social production on the basis of a 3-4-hour working day. But in fact (especially if you take fashion professions) the working day is increasing, mainly due to the fact that leisure penetrates all its pores. During the working day, music is downloaded and listened to, and films are even watched and mainly constant communication takes place through a growing number of channels: interconnectivity has become the new otium for the people $[8$, c. 50].

Moreover, the classical form of the industrial (traditional) type of labor undergoes significant changes: "The completely traditional industrial type work, which has not 
disappeared anywhere, and moreover, labor in the service sector today imitates the creative and becomes equally porous, flexible and potentially precarious" [8, c. 50].

Poyl Arora describes the transformation of the modern ethos of work in a very colorful way: "Billiard tables, volleyball courts, video game rooms, pianos, ping-pong tables and yoga rooms are a distinctive feature of the new work landscape. Bicycles, scooters and skaters provide mobility for employees. The game determines the design and furnishings of the reception room and boardroom. Individual companies are being replaced by corporate systems located in park areas similar to university buildings. The transition from an office to a hammock means a change in the perception among leading enterprises of how production space looks in today's business market. Therefore, it is not surprising that the leaders of the creative and electronic industries - Pixar, Apple or Google - decided to redesign their corporate offices in such a way that they resemble the gaming space" [1, c. 89-90].

So, the game replaces work, or rather, labor becomes a game, which means the complete triumph of the anthropological model of "Homo ludens", which replaces the previous model of "Homo faber". This represents not only a serious challenge not only to the traditional way of labor, but also to the whole traditional system of spiritual values, in which labor has a special moral value. In this context, we believe, it is necessary to consider the basic values of work ethics that are characteristic of the domestic philosophical culture in order to understand the global nature of modern modifications in the axiosphere of work ethics.

Taking into account all these factors, it is necessary to talk about the formation of a new work ethic, which, taking into account all the objective factors of our time, should contribute to the revival of the spiritual meanings of labor, without which labor is an alienated mechanistic activity aimed at surviving and adapting to the world.

It is especially important to talk about the rehabilitation of the moral value of labor in the context of the "social well-being of modern youth" (V. T. Lisovsky). The spiritual state of modern youth makes the problem of the axiological significance of work ethics particularly acute and relevant.

What can be relied upon in the formation of a new work ethic of our time? We believe that the leading role in this process belongs to philosophy. As A. P. Maltseva writes: "The assumption that in the twenty-first century a man who produces and consumes was replaced by a person who is entertaining and enjoying, is shared by many sociologists, psychologists, culturologists, as well as artists, priests and journalists, but it is philosophy comprehend the general intuition that defines the changes taking place in modern culture as the transformation of a consumer society into a society of desire" [7, c. 4].

We agree with this point of view, the essence of which is to see in philosophy a real methodology for understanding the processes occurring in the bowels of modern culture. Here the question can be posed as follows: can labor be made an object of desire, more specifically an object of moral desire?

To answer this question, it is necessary to consider the following aspects of the labor phenomenon:

1 the labor ethos of the Russian people;

2 Protestant ethics of labor;

3 the philosophy of economy in Russian philosophy;

4 the Christian value of labor;

5 the nature of labor in post-modern society.

The Protestant ethic of labor is the foundation for the formation of the values of Western civilization as a whole, and in particular the capitalist market economy. The classic works of W. Sombart "The Bourgeois", M. Weber "The Protestant Ethics and the Spirit of 
Capitalism", and J. A. Schumpeter "Capitalism, Socialism and Democracy" play a special role in uncovering this phenomenon. The definition of an entrepreneurial spirit given by Sombart is important: "An entrepreneurial spirit is a synthesis of thirst for money, a passion for adventure, ingenuity, and much more; the philistine spirit consists of a penchant for prudence and discretion, of prudence and thriftiness" [3, c. 19].

\section{Conclusion}

Obviously, the creation of a new work ethic is impossible without resorting to Christianity. On the one hand, there is an Old Testament understanding of labor as a curse, expressed in such famous words: "In the sweat of your face you will eat bread until you return to the ground from which you were taken; for you are dust, and you will return to dust " (Genesis 3-19), and on the other hand, there is a Christian blessing and apology of labor, expressed, for example, in such words-covenants of T. Carlyle:" The newest gospel of our time: Know your and do it ... Know what you can work on, and work like Hercules! There can be nothing better for you ... Older than all the preached Gospels, the Gospel was unprofitable, unspoken and nonetheless eradicable, eternally living, saying: Work and find prosperity in labor" [5, c. 297-300].

Regarding the nature of labor in postmodern society, the following can be said. Describing the Western attitude to work on the basis of the analysis of the book by J. Baudrillard, "Symbolic Exchange and Death", K. V. Patyrbaeva writes: "Previously (in societies preceding postmodernism) labor was productive, it was permeated with purposefulness. In postmodern society, everything is different $<\ldots .>$. Such work (also in the form of leisure) fills our whole life as fundamental repression and control, as the need to constantly do something at that time and in the place prescribed by the ubiquitous code. People must be put to business. The attitude that today develops toward work and includes a flexible schedule, staff mobility, retraining, ongoing professional training, autonomy and self-government, decentralization of the labor process, is all just an attempt to integrate people (and production) into the consumption system" [10, c. 244-245].

Thus, we can say that the axiological status of labor in modern culture has undergone significant changes under the influence of several factors, among which, firstly, the hedonistic attitude of consumer society, and secondly, civilizational factor of the emergence of a new anthropological type of "symbolic analysts", which replaced the traditional "homo faber".

\section{СПИСОК ЛИТЕРАТУРЫ}

1 Арора П. Фабрика досуга: производство в цифровой век // Логос. 2015. Т. 25, № 3 (105). С. 88-119.

2 Зиятдинов Р. Н. Отношение к труду как ценности: автореф. ... дис. канд. филос. наук. Пермь, 2004. 20 с.

3 Зомбарт В. Буржуа: Этюды по истории духовного развития современного экономического человека. М.: Наука, 1994. 443 с.

4 Ильин И. А. О тьме и просветлении. Книга художественной критики. Бунин Ремизов - Шмелев. Мюнхен: Тип. Обители преп. Иова Почаевского, 1959. $196 \mathrm{c.}$

5 Карлейль Т. Этика жизни. Трудиться и не унывать! М.: Республика, 1994. 415 с.

6 Липовеики Ж. Эра пустоты. СПб.: Владимир Даль, 2001. 158 с.

7 Мальиева А. П. Введение в философию желания. (Критический анализ опыта концептуализации феномена желания). М.: Наука, ФЛИНТА, 2014. 273 с. 
8 Маяцикий М. Otium для никого? // Логос. 2015. Т. 25, № 3 (105). С. 46-50.

9 Паривания B. В. Философия труда // Отчуждение человека в перспективе глобализации мира. Сб. филос. ст. СПб.: Петрополис, 2001. Вып. І. С. 262-273.

10 Патырбаева К. В. Современное общество, труд и человек в постмодернизме Ж. Бодрийара // Философия хозяйства. 2012. № 2 (80). С. 240-247.

11 Разин A. B. Исторические формы морали // Проблемы этики: философско-этический альманах. М.: Алькор Паблишерс, 2012. Вып. III. С. 4-22.

12 Сидорина T. Ю. «Ноmо faber» как символ эпохи труда: к истории эволюции понятия // Вопросы философии. 2015. № 3. С. 14-22.

13 Щукин В. Г. Город и свобода. Историко-культурные заметки // Вопросы философии. 2012. № 8. С. 61-71.

14 Simonova S. A, Dudareva M. A., Mikhalkin N. V., Yashina T. A., Zubashchenko Y. V. Metaphysics of Labor in Russian Culture: Part One // AMAZONIA INVESTIGA. 2019. Vol. 8. No 23. P. 868-874.

\section{REFERENCES}

1 Arora P. Fabrika dosuga: proizvodstvo v tsifrovoi vek [Leisure factory: production in a digital age]. Logos, 2015, vol. 25, no 3 (105), pp. 88-119. (In Russian)

2 Ziiatdinov R. N. Otnoshenie k trudu kak tsennosti [Attitude towards work as value: $\mathrm{PhD}$ thesis, summary]. Perm', 2004. 20 p. (In Russian)

3 Zombart V. Burzhua: Etiudy po istorii dukhovnogo razvitiia sovremennogo ekonomicheskogo cheloveka [Bourgeois: Studies on the history of a spiritual development of modern economic man]. Moscow, Nauka Publ., 1994. 443 p. (In Russian)

4 Il'in I. A. O t'me i prosvetlenii. Kniga khudozhestvennoi kritiki. Bunin - RemizovShmelev [About Darkness and Enlightenment. The Book of Art Criticism. Bunin Remizov - Shmelev]. Miunkhen, Tipografiia Obiteli prep. Iova Pochaevskogo Publ., 1959. 196 p. (In Russian)

$5 \quad$ Karleil' T. Etika zhizni. Trudit'sia i ne unyvat'! [Ethics of life. Work hard and not lose heart!] Moscow, Respublika Publ., 1994. 415 p. (In Russian)

6 Lipovetski Zh. Era pustoty [The era of emptiness]. St. Petersburg, Vladimir Dal' Publ., 2001. 158 p. (In Russian)

7 Mal'tseva A. P. Vvedenie $v$ filosofiiu zhelaniia. (Kriticheskii analiz opyta kontseptualizatsii fenomena zhelaniia) [Introduction to the philosophy of desire. (A critical analysis of the experience of conceptualizing the phenomenon of desire)]. Moscow, Nauka Publ., FLINTA Publ., 2014. 273 p. (In Russian)

8 Maiatskii M. Otium dlia nikogo? [Otium for anyone?]. Logos, 2015, vol. 25, no 3 (105), pp. 46-50. (In Russian)

9 Partsvaniia V. V. Filosofiia truda [Philosophy of labor]. In: Otchuzhdenie cheloveka $v$ perspektive globalizatsii mira. Sbornik filosofskikh statei [Alienation of man in the perspective of globalization of the world. Collection of philosophical articles]. St. Petersburg, Petropolis Publ., 2001, vol. I, pp. 262-273. (In Russian)

10 Patyrbaeva K. V. Sovremennoe obshchestvo, trud i chelovek v postmodernizme Zh. Bodriiara [Modern society, labor and man in the postmodernism of J. Baudrillard]. Filosofiia khoziaistva, 2012, no 2 (80), pp. 240-247. (In Russian)

11 Razin A. V. Istoricheskie formy morali [Historical forms of morality]. In: Problemy etiki: filosofsko-eticheskii al'manakh [Problems of ethics: philosophical and ethical almanac]. Moscow, Al'kor Pablishers Publ., 2012, vol. III, pp. 4-22. (In Russian) 
12 Sidorina T. Iu. "Homo faber" kak simvol epokhi truda: $\mathrm{k}$ istorii evoliutsii poniatiia ["Homo faber" as a symbol of the era of labor: on the history of evolution of the concept]. Voprosy filosofii, 2015, no 3, pp. 14-22. (In Russian)

13 Shchukin V. G. Gorod i svoboda. Istoriko-kul'turnye zametki [City and freedom. Historical and cultural notes. In: Issues of Philosophy]. Voprosy filosofii, 2012, no 8, pp. 61-71. (In Russian)

14 Simonova S. A, Dudareva M. A., Mikhalkin N. V., Yashina T. A., Zubashchenko Y. V. Metaphysics of Labor in Russian Culture: Part One. AMAZONIA INVESTIGA, 2019, vol. 8, no 23, pp. 868-874. (In English) 